Gut, 1974, 15, 94-98

\title{
Viral antibodies and autoantibodies in chronic liver disease
}

\author{
D. R. TRIGER, J. B. KURTZ ${ }^{1}$, AND RALPH WRIGHT \\ From the Department of Medicine, Royal South Hants Hospital, Southampton, and the Department of \\ Virology, Radcliffe Infirmary, Oxford
}

SUMMARY Our previous observations of highly significant increases in high titre antibodies to measles and rubella in patients with chronic active hepatitis have been extended and it has been shown that these reactions do not occur in other forms of liver disease. Significant increases in antibody titres to cytomegalovirus have also been found in patients with chronic active hepatitis $(\mathrm{P}<0.001)$ and alcoholic and primary biliary cirrhosis $(\mathbf{P}<0.05)$. Antibody titres to herpes simplex, varicella/zoster, parainfluenza I, and Mycoplasma pneumoniae in all forms of chronic liver disease did not differ from controls. Immunofluorescent autoantibodies were correlated with the viral antibodies and a highly significant correlation with strongly positive antismooth muscle and antinuclear antibodies and measles antibody titres in particular was noted. The possible significance of this correlation is discussed in terms of the hypothesis that the intact liver plays a significant role in the sequestering of antigens.

In a previous communication (Triger, Kurtz, MacCallum, and Wright, 1972) we have noted highly significant increases in high titre antibodies to measles and rubella viruses in patients with chronic active hepatitis. This report extends the earlier observations on antibodies to viral antigens and also examines the correlation with immunofluorescent autoantibodies in patients with chronic liver disease.

\section{Materials and Methods}

Sera were obtained from three groups of subjects. All sera were stored at $-20^{\circ} \mathrm{C}$ and were tested together against any given antigen. The tests were carried out on coded sera.

\section{CHRONIC ACTIVE HEPATITIS}

All patients were diagnosed as having chronic active hepatitis on the basis of histological features as described by de Groote, Desmet, Gedigk, Korb, Popper, Poulsen, Scheuer, Schmid, Thaler, Uehlinger, and Wepler (1968) together with

1Present address: Public Health Laboratory, Church Lane, Heavitree, Exeter, EX2 5AD.

Received for publication 21 November 1973. characteristic clinical and biochemical features (Mistilis and Blackburn, 1970). All sera were hepatitis B antigen-negative as tested by immunodiffusion. The 19 patients studied included 18 females and one male. Ages ranged from 13 to 81 with a mean of 52 years.

\section{CIRRHOSIS}

The nature of the cirrhosis was defined on the basis of characteristic clinical and histological findings in all cases. The 36 patients studied comprised 20 with cirrhosis secondary to alcohol and three with postnecrotic cirrhosis. Thirteen patients were diagnosed as primary biliary cirrhosis on the basis of positive antimitochondrial antibodies together with compatible histological features of the disease on liver biopsy (Scheuer, 1968). Ages ranged from 9 to 77 with a mean of 55 years. Twenty-four females and 12 males were included in the study.

\section{CONTROLS}

Control sera were obtained from laboratory staff, healthy relatives of hospital patients, and also from patients with a variety of diseases but with no evidence of hepatic damage. The majority of patients were recovering from cerebrovascular accidents and myocardial infarcts. The control sera were matched with those with liver disease by age and sex. 
Immunological Tests

VIRAL ANTIBODIES

Antibodies to measles, herpes simplex, varicella/ zoster, parainfluenza I (Sendai), cytomegalovirus, and Mycoplasma pneumoniae were tested by the standard complement-fixation technique (Bradstreet and Taylor, 1962). Antibodies to rubella were detected by the haemagglutination inhibition test. Herpes simplex and varicella/zoster antigen were prepared in the laboratory; the other viral antigens were supplied by the Standards Laboratory for Serological Reagents, Colindale. All tests were performed using a microtitre technique. Measles antigen was prepared in Vero cells, rubella antigens in BHK 21 cells, and cytomegalovirus antigen in human embryo fibroblasts.

\section{AUTOANTIBODIES}

Autoantibodies were detected by indirect immunofluorescence using rat liver, kidney, and rat gastric mucosa. These were graded by the intensity of fluorescent staining in four categories $(0, \pm,+$, and $++)$.

All sera were tested in a dilution of $1 / 10$ using Burroughs Wellcome fluorescein-conjugated antihuman IgG/IgM diluted $1 / 180$ in phosphatebuffered saline solution. Sections were examined using a Zeiss standard universal microscope with a quartz iodine lamp with a Balzer Fitc 3 filter and a Kodak Wratten gelatin barrier filter no. 12 .

\section{ABSORPTION STUDIES}

Sera from four patients with chronic active hepatitis were absorbed with measles antigen in order to investigate the possibility of cross-reactivity between measles antibody and the autoantibodies. Absorption was carried out using the Edmonston strain of measles virus grown in Vero cells $\left(10^{8}\right.$ cells $/ \mathrm{ml}$ of serum). Absorption using Vero cells alone was used as a control. Measles antibody titres were measured before and after absorption using an indirect immunofluorescence technique, since complementfixation techniques were unsuitable after absorption of the sera with measles antigen.

\section{Results}

The antibody titres to measles, rubella, and cytomegalovirus are shown in table I. Highly significant $(P<0.001)$ elevation in the titres to all three viruses in patients with chronic active hepatitis as well as significant $(\mathrm{P}<0.05)$ elevation in antibody titres to cytomegalovirus in cirrhotic patients is demonstrated. No difference in antibody titre between patients with alcoholic cirrhosis and those with primary biliary cirrhosis was detectable.

Table II shows the antibody titres to herpes simplex, varicella/zoster, parainfluenza $I$, and Mycoplasma pneumoniae in patients with cirrhosis and chronic active hepatitis compared with matched controls. The titres observed in all three groups were within normal limits and no differences were detectable.

\begin{tabular}{|c|c|c|c|c|c|c|c|c|c|c|}
\hline & \multicolumn{8}{|c|}{ Antibody Titre } & \multirow[b]{2}{*}{ Total } & \multirow[b]{2}{*}{$\mathbf{P}^{1}$} \\
\hline & $<1 / 32$ & $1 / 32$ & $1 / 64$ & $1 / 128$ & $1 / 256$ & $1 / 512$ & $1 / 1024$ & $>1 / 1024$ & & \\
\hline $\begin{array}{l}\text { Measles }(C F T) \\
\text { Controls } \\
\text { Cirrhosis } \\
\text { Chronic active hepatitis }\end{array}$ & $\begin{array}{r}11 \\
13 \\
2\end{array}$ & $\begin{array}{l}6 \\
5\end{array}$ & $\begin{array}{l}3 \\
6 \\
1\end{array}$ & $\begin{array}{l}3 \\
2 \\
2\end{array}$ & $\begin{array}{l}2 \\
1\end{array}$ & 3 & $\begin{array}{l}1 \\
1\end{array}$ & 9 & $\begin{array}{l}23 \\
29 \\
19\end{array}$ & $\begin{array}{l}\text { NS } \\
<0.001\end{array}$ \\
\hline & $<1 / 64$ & $1 / 64$ & $1 / 128$ & $1 / 256$ & $1 / 512$ & $1 / 1024$ & $1 / 2048$ & $>1 / 2048$ & & \\
\hline $\begin{array}{l}\text { Rubella }(H A I) \\
\text { Controls } \\
\text { Cirrhosis } \\
\text { Chronic active hepatitis }\end{array}$ & $\begin{array}{r}4 \\
11 \\
4\end{array}$ & $\begin{array}{l}7 \\
4 \\
1\end{array}$ & $\begin{array}{l}3 \\
6 \\
1\end{array}$ & $\begin{array}{l}1 \\
4\end{array}$ & $\begin{array}{l}2 \\
1 \\
3\end{array}$ & 1 & 5 & 2 & $\begin{array}{l}17 \\
27 \\
16\end{array}$ & $\begin{array}{l}\text { NS } \\
<0.01\end{array}$ \\
\hline & $<1 / 16$ & $1 / 16$ & $1 / 32$ & $1 / 64$ & $1 / 128$ & $1 / 256$ & $1 / 512$ & $>1 / 512$ & & \\
\hline $\begin{array}{l}\text { Cytomegalovirus (CFT) } \\
\text { Controls } \\
\text { Cirrhosis } \\
\text { Chronic active hepatitis }\end{array}$ & $\begin{array}{l}6 \\
6\end{array}$ & $\begin{array}{l}8 \\
5\end{array}$ & $\begin{array}{l}4 \\
1\end{array}$ & $\begin{array}{l}3 \\
6 \\
4\end{array}$ & $\begin{array}{l}8 \\
6\end{array}$ & $\begin{array}{l}1 \\
1\end{array}$ & $\begin{array}{l}1 \\
3\end{array}$ & 2 & $\begin{array}{l}21 \\
28 \\
16\end{array}$ & $\begin{array}{l}<0.05 \\
<0.001^{2}\end{array}$ \\
\hline
\end{tabular}

Table I Antibody titres to measles, rubella, and cytomegalovirus in chronic liver disease

${ }^{1}$ Statistical significance ( $x^{2}$ test) in relation to controls

Dividing line: Measles $1: 128$

Rubella $1: 256$

${ }^{2}$ Difference between cirrhosis and chronic active hepatitis $p<0.05$ 


\begin{tabular}{|c|c|c|c|c|c|c|c|c|}
\hline & \multicolumn{6}{|c|}{ Antibody Titre } & \multirow[b]{2}{*}{ Total } & \multirow[b]{2}{*}{$\mathbf{P}^{1}$} \\
\hline & $<1 / 16$ & $1 / 16$ & $1 / 32$ & $1 / 64$ & $1 / 128$ & $>1 / 128$ & & \\
\hline \multirow[t]{2}{*}{$\begin{array}{l}\text { Herpes Simplex }(C F T) \\
\text { Controls } \\
\text { Cirrhosis } \\
\text { Chronic active hepatitis }\end{array}$} & $\begin{array}{l}8 \\
8 \\
3\end{array}$ & $\begin{array}{l}5 \\
2 \\
2\end{array}$ & $\begin{array}{c}6 \\
10 \\
7\end{array}$ & $\begin{array}{l}3 \\
2\end{array}$ & $\begin{array}{l}2 \\
2\end{array}$ & & $\begin{array}{l}19 \\
25 \\
16\end{array}$ & $\begin{array}{l}\text { NS } \\
\text { NS }\end{array}$ \\
\hline & & $<1 / 16$ & $1 / 16$ & $1 / 32$ & $1 / 64$ & $>1 / 64$ & & \\
\hline \multirow[t]{2}{*}{$\begin{array}{l}\text { Varicella/Zoster (CFT) } \\
\text { Controls } \\
\text { Cirrhosis } \\
\text { Chronic active hepatitis }\end{array}$} & & $\begin{array}{l}14 \\
23 \\
10\end{array}$ & $\begin{array}{l}2 \\
1 \\
2\end{array}$ & 1 & $\begin{array}{l}1 \\
2 \\
1\end{array}$ & & $\begin{array}{l}18 \\
26 \\
15\end{array}$ & $\begin{array}{l}\text { NS } \\
\text { NS }\end{array}$ \\
\hline & & $<1 / 16$ & $1 / 16$ & $1 / 32$ & $>1 / 32$ & & & \\
\hline \multirow[t]{2}{*}{$\begin{array}{l}\text { Parainfluenza I (Sendai) } \\
\text { Controls } \\
\text { Cirrhosis } \\
\text { Chronic active hepatitis }\end{array}$} & & $\begin{array}{l}6 \\
4 \\
4\end{array}$ & $\begin{array}{l}2 \\
2\end{array}$ & 1 & & & $\begin{array}{l}9 \\
4 \\
6\end{array}$ & $\begin{array}{l}\text { NS } \\
\text { NS }\end{array}$ \\
\hline & & $<1 / 16$ & $1 / 16$ & $1 / 32$ & $1 / 64$ & $>1 / 64$ & & \\
\hline $\begin{array}{l}\text { Mycoplasma Pneumoniae } \\
\text { Controls } \\
\text { Cirrhosis } \\
\text { Chronic active hepatitis }\end{array}$ & & $\begin{array}{r}7 \\
6 \\
10\end{array}$ & 1 & 1 & $\begin{array}{l}1 \\
1\end{array}$ & & $\begin{array}{r}9 \\
8 \\
10\end{array}$ & $\begin{array}{l}\text { NS } \\
\text { NS }\end{array}$ \\
\hline
\end{tabular}

Table II Antibody titres to herpes simplex, varicella/zoster, parainfluenza I, and Mycoplasma pneumoniae in chronic liver disease

${ }^{1}$ Statistical calculation using $1: 16$ as dividing line for each virus,

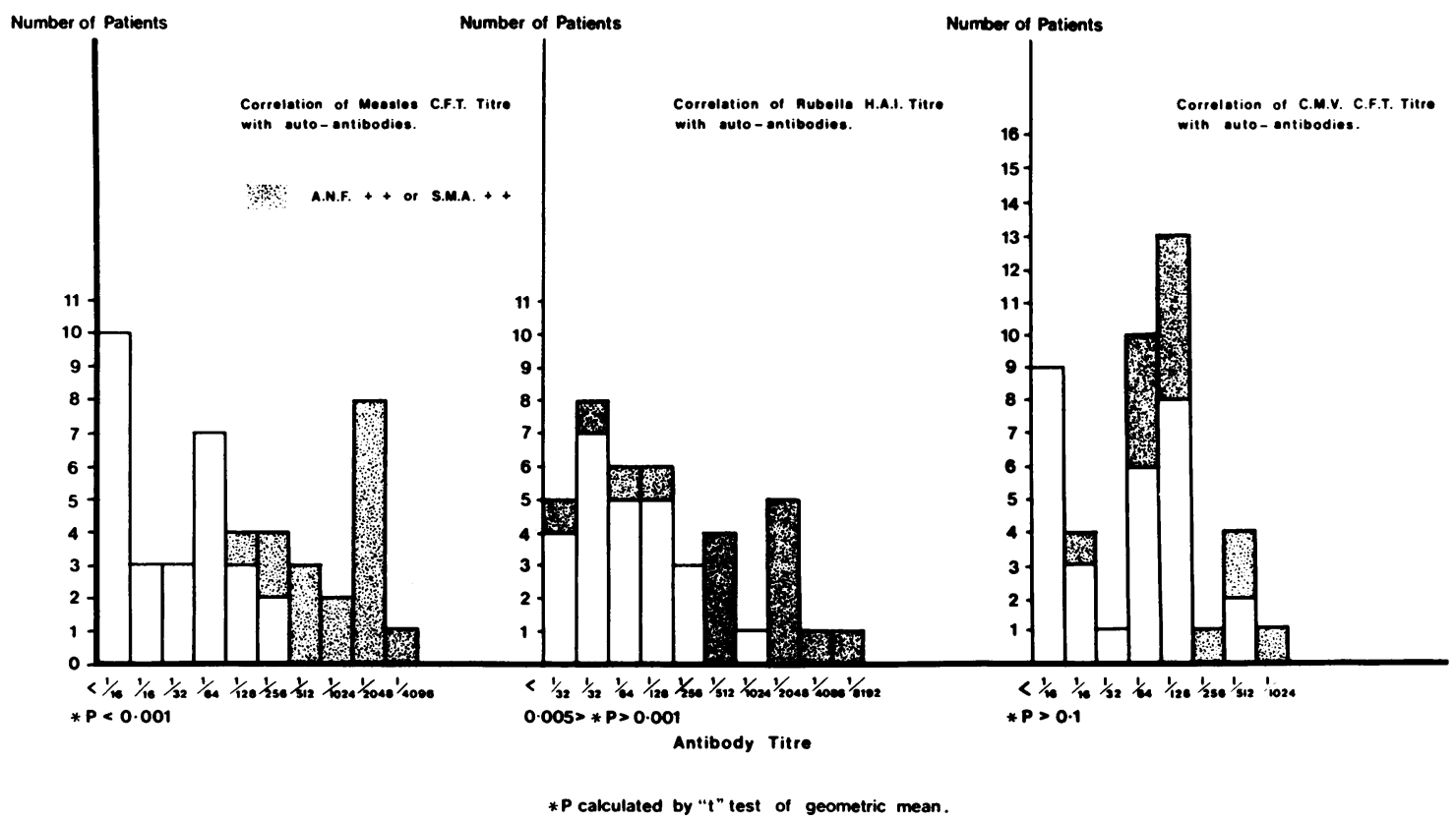

Fig Correlation between viral antibody titres and autoantibodies 


\begin{tabular}{|c|c|c|c|c|c|c|}
\hline \multirow{3}{*}{ Serum Code No. } & \multicolumn{2}{|c|}{ Unabsorbed Sera } & \multicolumn{4}{|l|}{ Absorbed Sera } \\
\hline & \multirow[t]{2}{*}{ Autoantibody ${ }^{1}$} & \multirow[t]{2}{*}{ Measles Antibody } & \multicolumn{2}{|c|}{ With Vero Cells } & \multicolumn{2}{|c|}{$\begin{array}{l}\text { With Vero Cells and Measles } \\
\text { Antigen }\end{array}$} \\
\hline & & & Autoantibody & $\begin{array}{l}\text { Measles } \\
\text { Antibody }\end{array}$ & Autoantibody & $\begin{array}{l}\text { Measles } \\
\text { Antibody }\end{array}$ \\
\hline $\begin{array}{l}70-03-9 \\
70-10-4 \\
71-84-2\end{array}$ & $\begin{array}{l}\text { SMA + } \\
\text { SMA + } \\
\text { ANA + } \\
\text { SMA }++\end{array}$ & $\begin{array}{l}1: 2048 \\
1: 4096 \\
1: 1024\end{array}$ & $\begin{array}{l}\text {-ve } \\
\text { SMA }\end{array}+$ & $\begin{array}{l}1: 1024 \\
1: 2048 \\
1: 1024\end{array}$ & $\begin{array}{l}\text { - ve } \\
\text { SMA + } \\
\text { SMA + }\end{array}$ & $\begin{array}{r}1: 64 \\
<1: 64 \\
<1: 64\end{array}$ \\
\hline $74-46-1$ & $\begin{array}{l}\text { SNA } \pm \\
\text { SMA }++\end{array}$ & $1: 2048$ & SMA \pm & $1: 1024$ & SMA + & $1: 64$ \\
\hline
\end{tabular}

Table III Absorption studies of measles antigen and immunofluorescent autoantibodies in chronic active hepatitis

ISMA = antismooth muscle antibody, ANA antinuclear antibody

The correlation between the immunofluorescent autoantibodies and the viral antibody titres is shown in the figure. The sera have been divided into two groups: those showing strongly positive $(++)$ antismooth muscle or antinuclear antibodies, and those showing none or weakly positive autoantibodies. A good correlation was obtained between the autoantibodies and measles antibody titres, a fair correlation with rubella antibody titres, and none with cytomegalovirus antibody titres. No correlation was observed between antimitochondrial antibody titres and any of the viral antibodies.

The results of absorbing the sera with measles antigen are shown in table III. Absorption with the antigen grown in Vero cells resulted in the removal of most of the measles antibody together with the removal of the bulk of the autoantibodies. Vero cells alone absorbed out the autoantibodies to a similar extent without significantly affecting the measles antibody titre. These studies suggest that the correlation between measles antibody titres and autoantibodies is unlikely to be due to crossreacting antigens.

\section{Discussion}

In the present study we have shown that the high antibody titres to measles and rubella viruses observed in chronic active hepatitis are confined to that form of liver disease and are not present in patients with alcoholic cirrhosis or primary biliary cirrhosis. By contrast, cytomegalovirus antibody titres are elevated in cirrhosis as well as in chronic active hepatitis. The elevated titres to cytomegalovirus confirm a trend present in the study of Toghill Williams, and Stern (1969). These authors, when examining the possible role of cytomegalovirus in the pathogenesis of chronic liver disease, found no increase in the incidence of antibodies compared with controls, but 21 out of 56 patients with chronic liver disease had antibody titres of 1:64 or greater, a titre which is seldom observed in healthy controls.

An additional positive finding in the present study is a strong correlation between high titre measles and rubella virus antibodies and autoantibodies in chronic active hepatitis. In this context it is of interest that elevated antibody titres to measles and rubella viruses have been reported in autoimmune disorders such as systemic lupus erythematosus (Hollinger, Sharp, Lidsky, and Rawls, 1971; Phillips and Christian, 1970; Rothfield, Evans, and Niederman, 1972), whereas cytomegalovirus antibody titres are normal in this condition (Rothfield et al, 1972; Kalliomaki and Halonen, 1972). High measles antibody titres have also been noted in patients with a variety of autoantibodies (Lucas, Brouwer, Feltkamp, Ten Veen, and Van Loghem, 1972) but other viral antibodies were not studied.

We have considered possible explanations for the high antibody titre to exogenous viral, bacterial, and dietary antigens observed in chronic active hepatitis elsewhere (Triger and Wright, 1973). These include failure of Kupffer cells to sequester such antigens or their abnormal response or an enhanced ability to produce antibody to certain antigens in liver disease because of a general hyperreactivity of the antibodyforming system.

The correlation between high measles and rubella antibodies and autoantibodies which we have observed here enables us to examine one possibility directly, namely, that there might be a cross reactivity between viral antigens and autoantigens. Antigenic cross reactivity has been demonstrated between streptococci and heart antigens (Kaplan and Meyeserian, 1962) and enterobacteria and colonic epithelial antigen (Perlmann, Hammarström, Lagercrantz, and Campbell, 1967). Such cross reaction seems unlikely to explain our findings. Although absorbing the sera with measles antigen significantly reduced the immunofluorescent anti- 
body titre, this was due almost entirely to the Vero cells on which the measles virus was grown, as absorption with these cells alone reduced the autoantibody titre without significantly altering the measles antibody titres. In addition it has been shown (Hollinger et al, 1971) that removal of the antinuclear antibodies by absorbing with mouse liver nuclei does not alter the viral antibody titre. The lesser correlation with rubella antibody titres may be associated with the finding that circulating antibodies to rubella do not occur as frequently in the adult population as do measles antibodies.

The lack of correlation between antismooth muscle and antinuclear antibody titres and cytomegalovirus antibody levels might be expected in view of the finding of elevated cytomegalovirus antibody titres in types of liver disease not usually associated with high titres to these autoantibodies. This suggests that the explanation of the high antibody titres to cytomegalovirus may differ from that for measles and rubella. Whatever the mechanism a feature common to these viruses is that infection with all three is commonly associated with a viraemia, whereas this is unusual in the infections with the viruses studied in which low antibody titres were found.

We wish to thank Professor P. B. Beeson and Dr F. O. MacCallum for their continuing interest and for providing facilities for this work. We are grateful to Mr Ivor Chinn and Mr Ron Lloyd for technical assistance.
References

Bradstreet, C. M. P., and Taylor, C. E. D. (1962). Technique of complement-fixation test applicable to the diagnosis of virus diseases. Mth. Bull. Minist. Hlth Lab. Serv., 21, 96-104.

De Groote, J., Desmet, V. J., Gedigk, P., Korb, G., Popper, H., Poulsen. H., Scheuer, P. J., Schmid, M., Thaler, H., Uehlinger, E., and Wepler, W. (1968). A classification of chronic hepatitis. Lancet, 2, 626-628.

Hollinger, F. B. Sharp, J. T., Lidsky, M. D., and Rawls, W. E. (1971). Antibodies to viral antigens in systemic lupus erythematosus. Arthr. and Rheum., 14, 1-11.

Kalliomaki, J. L., and Halonen, P. (1972). Antibody levels to parainfluenza, herpes simplex, varicella-zoster, cytomegalo virus, and measles virus in patients with connective tissue diseases. Ann. rheum. Dis., 31, 192-195.

Kaplan, M. H., and Meyeserian, M. (1962). An immunological crossreaction between Group A streptococcal cells and human heart tissue. Lancet, 1, 706-710.

Lucas, C. J., Brouwer, R., Feltkamp, T. E. W., Ten Veen, J. H., and Van Loghem, J. J. (1972). Measles antibodies in sera from patients with autoimmune diseases. Lancet, 1, 115-116.

Mistilis, S. P., and Blackburn, C. R. B. (1970). Active chronic hepatitis. Amer. J. Med., 48, 484-495.

Perlmann, P., Hammarström, S., Lagercrantz, R., and Campbell, D. (1967). Autoantibodies to colon in rats and human ulcerative colitis: cross reactivity with Escherichia coli 0:14 antigen. Proc. Soc. exp. Biol. (N.Y.), 125, 975-980.

Phillips, P. E., and Christian, C. L. (1970). Myxovirus antibody increases in human connective tissue disease. Science, 168, 982-984.

Rothfield, N. F., Evans, A. S., and Niederman, J. C. (1972). Clinical and laboratory aspects of raised virus antibody titres in systemic lupus erythematosus. Ann. rheum. Dis., 32, 238-246.

Scheuer, P. J. (1968). Liver Biopsy Interpretation, p. 22. Bailliere Tindall, and Cassell, London.

Toghill, P. J., Williams, R., and Stern, H. (1969). Cytomegalovirus infection in chronic liver disease. Gastroenterology, 56, 936-937.

Triger, D. R., Kurtz, J. B., MacCallum, F. O., and Wright, R. (1972). Raised antibody titres to measles and rubella viruses in chronic active hepatitis. Lancet, 1, 665-667.

Triger, D. R., and Wright, R. (1973). Hyperglobulinaemia in liver disease. Lancet, 1, 1494-1496. 